\title{
Challenges of nursing teaching-learning to care for human dying - professors' perceptions
}

\author{
Desafios de ensino-aprendizagem da Enfermagem para o cuidado frente ao morrer \\ humano - percepções docentes \\ Desafíos de enseñanza-aprendizaje de la Enfermería para el cuidado frente al morir \\ humano - percepciones docentes
}

Emanuelle Caires Dias Araújo Nunes ${ }^{1}$ Andressa de Andrade Santos ${ }^{1}$

1. Universidade Federal da Bahia.

Vitória da Conquista, Bahia, Brazil.
Corresponding Author:

Emanuelle Caires Dias Araújo Nunes.

E-mail: emanuelecdanunes@gmail.com

Submitted on $04 / 19 / 2017$

Accepted on 08/28/2017.

DOI: 10.1590/2177-9465-EAN-2017-0091

\begin{abstract}
The objective of this study was to investigate professors' perceptions about their experiences in the teaching-learning process of nursing care in relation to dying. This is a descriptive-exploratory, qualitative research, delimited by data saturation, was carried out with 11 nursing professors from three higher education institutions. Data collection involved the drawing-text theme technique and a semi-structured interview. Analysis used the technique of collective subject discourse. The results identified three categories: How I would like to take care in the context of finitude - my challenge; Challenging fragilities in the teaching of nurses in the context of care concerned with death and dying; Strategies to compensate or promote more substantial nurse training related to care in finitude. We conclude that the graduation of the nurses studied did not satisfactorily develop the necessary skills and abilities to deal with human death and dying. This study infers the need of permanent education to support transformations in this area.
\end{abstract}

Keywords: Death; Education; Nursing; Care.

\section{Resumo}

Objetivou desvelar percepções de docentes sobre a vivência no processo de ensino-aprendizagem para o cuidado de Enfermagem frente ao morrer humano. Trata-se de pesquisa descritivo-exploratória, de abordagem qualitativa, realizada em três instituições de ensino superior, com 11 enfermeiros docentes, delimitados pela saturação dos dados. A coleta envolveu as técnicas desenho-texto-tema e entrevista semiestruturada. A análise utilizou a técnica do Discurso do Sujeito Coletivo. Os resultados evidenciam três categorias: Como eu gostaria de cuidar no contexto da finitude - meu desafio; Fragilidades desafiadoras à formação de Enfermagem no contexto de cuidados frente à morte e ao morrer; Estratégias de compensação ou promoção de uma formação em Enfermagem mais substancial para o cuidado na finitude. Concluímos que o contexto de formação de enfermeiros estudado não atende satisfatoriamente ao desenvolvimento de habilidades e competências para o cuidado frente à morte e ao morrer humanos. O estudo infere a Educação Permanente como subsídio às transformações nesta área.

Palavras-chave: Morte; Formação; Enfermagem; Cuidado.

\section{Resumen}

El objetivo del estudio fue de revelar las percepciones docentes sobre su experiencia en el proceso de enseñanza-aprendizaje para el cuidado de Enfermería frente al morir humano. Se trata de una investigación descriptivo-exploratoria, cualitativa realizada en tres instituciones de enseñanza superior con 11 enfermeros docentes, delimitados por la saturación de los datos. La recolección involucró la técnica diseño-texto-tema y entrevista semiestructurada. El análisis utilizó la técnica del Discurso del Sujeto Colectivo. Los resultados evidencian tres categorías: Como me gustaría cuidar en el contexto de la finitud - mi desafío; Fragilidades desafiadoras a la formación de Enfermería en el contexto de cuidados frente a la muerte y al morir; Estrategias de compensación o promoción de una formación en Enfermería más sustancial para el cuidado en la finitud. Concluimos que el contexto de formación de enfermeros estudiado no lleva al cabo satisfactoriamente al desarrollo de habilidades y competencias para el cuidado frente a la muerte y al morir humanos. El estudio infiere la Educación Permanente como subvención a las transformaciones en esta área.

Palabras clave: Muerte; Formación; Enfermería; Cuidado. 


\section{INTRODUCTION}

The process of death and dying has undergone transformations throughout history and it is understood in different ways depending on the context into which it is inserted. ${ }^{1}$ Questions of death and dying are considered events that are uncomfortable in contemporary society, since historically this process has been distanced from the day-to-day life of society; for man the death of others brings to mind his own end. ${ }^{2}$

In this regard, the end of life is still synonymous with failure, sadness, anguish, and in particular fear, ${ }^{3,4}$ and is associated with injustice, since it interrupts the life trajectory, thus arousing feelings of indignation and frustration in caregivers. ${ }^{5}$

However, the understanding of death as part of the life cycle, especially from the point of view of health professionals, demands the capacity to be distinctive care professionals during the process of dying, in order to provide dignity and respect to the individual who is going through this change. ${ }^{6}$ Thus, it is essential to welcome the experience related to death of nursing students in order to minimize the resistance of future professionals to end-of-life care. Proper training would help ensure that these professionals develop skills to provide quality care to patients and families, minimizing the impact of death and preventing emotional exhaustion. ${ }^{7}$

However, the training of health professionals has superficially dealt with the issue of death, giving more emphasis on discussions of curative approaches, which diminishes the training opportunities of the graduating nurse, hindering the practice of care related to human death and dying. ${ }^{8}$

This fact is highlighted by the few subjects taught in the undergraduate curricula of health courses that deal with this theme that are insufficient for a sensitive approach to care in face of the human needs during this phase..$^{9}$ In nursing especially, the approach to the issue of death and palliative care during graduation is superficial, pointing to a vocational training lacking strategies to develop skills in this area, which are possible according to findings from other studies. ${ }^{10}$

In this context, the challenge of the undergraduate nursing professor is to develop a better approach to education in respect to death that allows closer care of the patient and his/her relatives when faced with the end of life. In order to do this, professors should develop abilities to work with this theme, so courses should provide strategies that promote awareness and improve skills to deal with this theme. ${ }^{11}$

Therefore, the relevance of this study is shown by the need to discuss and increase knowledge that contributes to scientific evidence on discussions about care for death and dying within the nursing curricula. The observation that few studies were found on this subject in biomedical databases reinforces and further justifies the importance of this research in investigating the guiding question: how do nursing professors perceive the teaching-learning process of the nursing curriculum in respect to care when faced with death?

Based on this guiding question, this study aimed to investigate professors' perceptions about their experience in the teaching-learning process of nurses in respect to human death.

\section{METHOD}

This is a descriptive-exploratory study with a qualitative approach carried out in three higher education institutions in the southwestern region of the State of Bahia. The institutions were two public universities, one federal (Campus Anísio Teixeira, Federal University of Bahia - UFBA) and one state (State University of the Southwest of Bahia - UESB) and one private university (Independent Faculty of the Northeast - FAINOR). The participants, 11 nurses, were included as they fulfilled the following criteria: to be professors of the undergraduate Nursing courses, to have acted in this type of setting for at least two years, and to have had at least one year of experience in care practice. Selection followed the non-probabilistic technique for convenience, according to accessibility. The number of participants was delimited by saturation of data and all signed informed consent forms. The research was approved by the Research Ethics Committee of the Federal University of Bahia (Campus Anísio Teixeira) - protocol number: 1.651.116 - CAAE: 55796516.0.0000.5556, in compliance with the Declaration of Helsinki and Resolution 466/12 of the Brazilian Ministry of Health. Data collection took place in the period from July to September 2016 and used multiple techniques: drawing-text theme, a semi-structured interview and documentary analysis. The design was chosen in order to access the subjective expression of the professors. Crayons, a pencil, rubber and a white sheet of A4 paper were available for the drawing. The stimulus for drawing was: What is the meaning of caring in the context of death? After completing the drawing, the participant was asked to explain the drawing and to assign a title, with this information being recorded and later transcribed. The text and title were used to anchor the image, adding resources to its analysis and interpretation from the dialogue. ${ }^{12}$

The semi-structured interview comprised five questions on the subject. The interviews were recorded on an MP4 recording device allowing a complete transcription of the responses. As additional sources of data, a documentary analysis was made of the curricular components cited in the interviews of the institutions involved (Graph 1). These totaled seven curricular components: three syllabuses on Basic and Fundamental Nursing, two on Ethics and Bioethics and two on Elderly Health. The analytical process was based on the collective subject discourse technique (CSD) that uses statements in the first person singular representing the collectivity of the study 
participants. CSD consists of key expressions, central ideas and methodological anchoring in which the key expressions consist of passages, transcripts of the discourse that are highlighted by the researcher because they reveal the essence of the testimony, or the content of the discourse. This is a kind of empirical proof of discourse, which becomes the raw material of the discourse of the collective subject. The central ideas are linguistic expressions that reliably describe the sense of the person's dialog; this is not an interpretation, but a description of the meaning of the statement or set of statements. ${ }^{13}$

\section{RESULTS}

The participants of this study were 11 female nursing professors aged between 29 and 58 years of age; their time of training was between nine and 33 years and their teaching career had lasted between two and 24 years. The analysis pointed to three categories of discussion.

\section{Category I: How I would like to take care in the context of finitude - my challenge}

\section{Subcategory IA: The end-of-life individual}

My understanding is that the nurse must take care of the individual throughout his life cycle, including at the time of death. In the same way that I am happy to take care of a child being born, I must also be pleased to be present at this other extreme. The whole care process for this patient who is leaving must maintain the zeal, respect and ethics. It must be developed in a spiritual, loving way, with compassion, gentleness and cordiality because I understand that the person needs to have a dignified, comfortable, pain-free death with little suffering. So we must take into account that this is the last care that we will give and it should be thought through with respect, because even though the patient is unknown to us, he is important to someone. Someone will miss him and will cry. We cannot lose the essence of the care of this moment. (CSD IA)

\section{Subcategory IB: The family facing death and dying}

Care should not only be offered to the patient in this process, but also to his family. You must also take care of this family, they will miss him, they will cry and they need to be protected. It is us [nurses] who often give the first support until other family members arrive, so we must take care to make ourselves present at this difficult time. $(C S D I B)$
Category II: Challenging fragilities in the teaching of nurses in the context of care concerned with death and dying

\section{Subcategory IIA: Being human and being a nursing student - an encounter with the suffering and insecurity of caring for the end of the other}

When the student is there working and there is a situation that the patient may die, she does not feel prepared because she does not have the maturity to act in that case. It is a time when they do not feel well, they are overwhelmed easily. When we are going to perform body preparation in the field, some do not want to participate. We have to call them and know why they do not want to, since it is part of our profession and they will go through this situation in the professional life. And when we work it out in class, they always cry. Lately we have even noticed occurrences of mental suffering in nursing students who cannot elaborate the experiences of the course. So I think these issues need to be worked out. (CSD IIB)

\section{Subcategory IIB: The teaching dilemma in nursing education}

I do not feel empowered to teach how the student will handle this. I think my limitations are very restricted to the fact that often I do not know how to deal with the situation, because we deal with it in a very technical way and it is not just technical. We deal more with the patient's physiological problems and the issues of fear, anxiety, and anguish are not seen as priorities. I already had to work with student groups that were very shocked by patients' deaths. My biggest limitation was to manage the feelings they present in class because you have to stop the class to give these people attention so that they can reflect on what it was that moment and how the next time will be. A big problem right now is that we ourselves are not prepared to deal with death, mourning, the bereaved family. (CSD IIB)

\section{Subcategory IIC: Evidence of an insufficient curricular approach to care in human finitude}

The university has to prepare students and society because death is a certainty, but the approach to death and dying is inadequate. We work in a very fragmented way within the disciplines, without contextualizing, generally, we center this approach only in a class that talks about death and body preparation, but the focus is procedural ability, not attitudinal or relational ability; we do not speak of the other aspects of death. The syllabus itself, does not allow 
me to do this and I think it should be a cross-sectional theme not in the sense of quoting, but in the sense of working in a cultural, sociological way. It is necessary to work more on the subject of death, to include more and to rethink it because there is a gap in the teaching. It requires a change in the entire nursing curriculum so that it is integrated, in which we do not work with isolated disciplines. Thus, everyone would work on all the subjects, since when you work with active methodologies you stimulate the student to reflect, to think and to analyze critically every situation, this facilitates the growth and autonomy of that student. (CSD IIC)

Such evidence is reinforced by the analysis of the syllabuses of the disciplines mentioned in the interviews as shown in the following Graphic 1.

Graphic 1. Analysis of curricular components of nursing undergraduate courses at UFBA (Campus Anísio Teixeira), UESB and FAINOR for the year 2016.

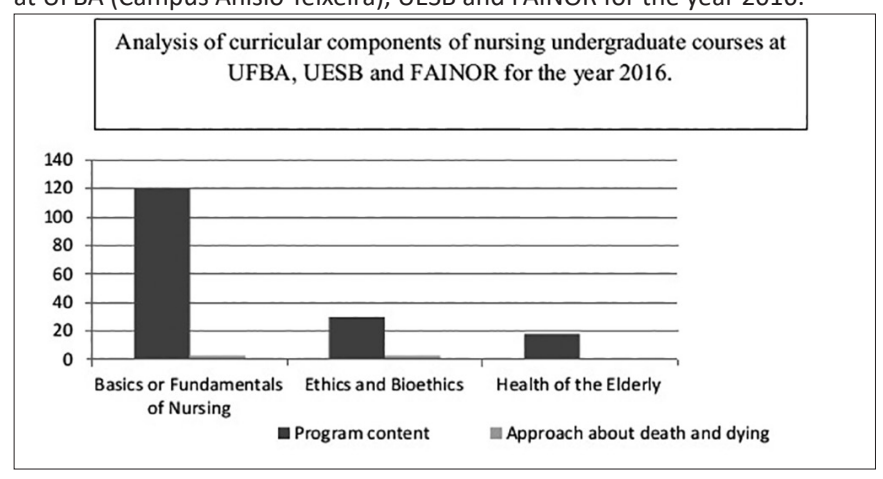

Category III: Strategies to compensate or promote more substantial nurse training related to care in finitude

\section{Subcategory IIIA: Beyond my training - to be human-professor sensitive to the pedagogical challenge of caring for human finitude}

The nurse needs to transcend this, she needs to have the will to transpose the values in which she was molded and to develop other knowledge and principles that will send her to an existential concreteness so that she can then work this moment, live this moment and care for the people who face this moment. It takes sensitivity to take care of the other, to have empathy to care for people and this will start from the person herself, from wanting to be, from overcoming some paradigms that they were taught and from allowing herself to continue constructing other views about care, especially at this moment of human death and dying. (CSD IIIA)

\section{Subcategory IIIB: Beyond the university - the permanent psychosocial and spiritual teaching of the being who will be a nurse}

I do not think that the university or academic teaching is responsible for this alone. It has a share of responsibility, but people and families need to address this in their relational cycle, they need to discuss. We often see that parents do not take their children to a wake, so how does this child grow up valuing and respecting this moment? This needs to be worked out culturally. I think it is a discussion beyond the academic walls and it should start there in early childhood, in parenting meetings, in religious groups, in relational media so it is not seen as something so distant as it is so close and real. So it is necessary to have more preparation because death is still something that distances a lot of people, it is a taboo, so maybe my greatest difficulty is a cultural issue, not knowing how to approach this in a more profound way, after all we end up bringing much of what we learn culturally to our pedagogical practice. (CSD IIIB)

\section{DISCUSSION}

\section{Category I: How I would like to take care in the context of finitude - my challenge}

The first category presented the figure 1 and the discourses that refer to the care considered by professors as ideal in the process of finitude, both for the individual who experiences dying and for the family that accompanies this process.

Figure 1. Support for the transition to death. Source: designed by the research subjects.

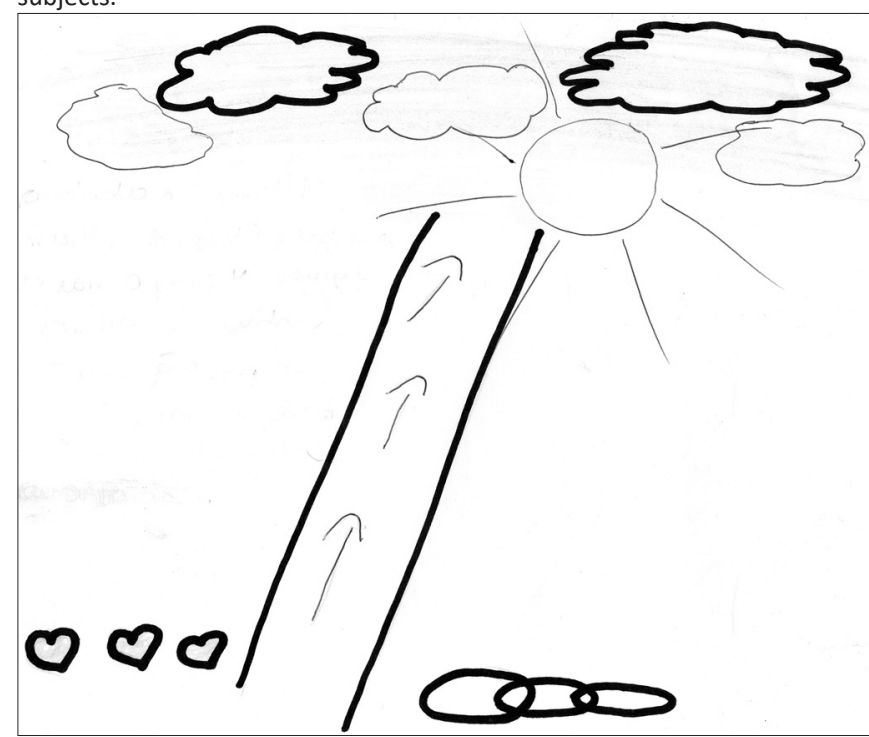


To this result, care must be present in the face of the finitude of life, since death is a part of existence, and it is therefore necessary to maintain the dignity of each individual during the process of dying and death constantly. ${ }^{6}$ Despite this, research generally points to gaps in end-of-life care, such as a study that reported that nurses most focused on the symptoms of the terminally ill rather than assessing additional factors such as their spiritual beliefs, family ties, and social connections. These are aspects relevant to the preparation for the end of life and a better family response to the patient's suffering. ${ }^{14}$

In this sense, the caring practice in which the behavior of love manifests, intensifies the relationship between patient, professional and family, generating tranquility, trust and harmony between the individuals to contribute to the reconstitution (healing) of the individual who experiences the possibility of death. Thus, it is necessary for nurses to surpass the paradigms of medical and biological science and to transform the science of its profession into its art. ${ }^{15}$

From this perspective, within the scope of public health, the family is gradually assuming an important role in the context of care, a fact evidenced by the transformations that arose with the proposals of changes in the care model. Thus, through the Family Health Strategy (FHS), promotion, prevention and recovery practices are focused on the family system, seeking to consolidate the principle of integrality proposed by the Brazilian National Health System (SUS). ${ }^{16}$

In other countries, there is also a lack of proximity between professionals and families in the home setting. In this sense, data from a study reports a lack of interest in palliative home care among Quebec family physicians, while pointing out the integration of nurses who practice palliative care in home care teams as important to stop the current trend of patients dying in hospitals at a great cost to the system. ${ }^{17}$

Another international study reinforces the importance of family participation in the end-of-life care of their loved one, even when the patient is hospitalized and in intensive care. The results reported good communications, expressions of empathy, explanations about the processes of therapeutic limitations and support for shared decision making as predictors of family satisfaction. These attitudes therefore emerge as important positive impact factors in the context of hospital palliative care. ${ }^{18}$

In this context, regardless of the setting, home or hospital, it is essential that the nurse is available to offer support and be truly present, thus assuming a welcoming position that facilitates improved aptitudes. It is important to be able to communicate to provide a vehicle to create security and trust in each other, encouraging communication, compassion and hope as a determining element for the satisfaction of the care provided. ${ }^{19}$

\section{Category II: Challenging fragilities in the teaching of nurses in the context of care concerned with death and dying}

Category II highlights the main limitations and shortcomings of approaching the issue of death in the teaching process of nurses. It is divided into three subcategories: Being human and being a nursing student - an encounter with the suffering and insecurity of caring for the end of the other, the teaching dilemma in nursing education and evidence of an insufficient curricular approach to care in human finitude. This category is well represented by Figure 2: Care-relational universe in the context of death, allusive to the social and contextual universe of the nurse. The CSD of this category points out that the main difficulties encountered by nurses to deal with death and dying are related to the teaching process they had.

Figure 2. Care-relational universe in the context of death. Source: designed by the research subjects.

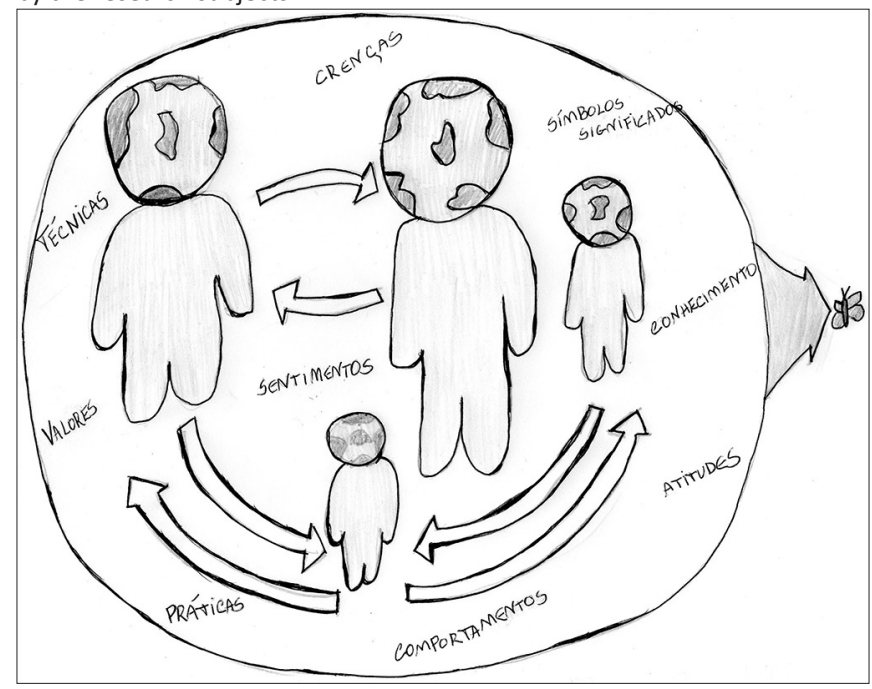

Thus, the process of death and dying is a challenge for the student due to the lack of preparation that the professionals of the area demonstrate in coping with death, a behavior responsible for enhancing the feelings of impotence and aversion generated during graduation. ${ }^{20}$

These feelings converge in insecurity and self-perception of unpreparedness to exercise care after a diagnosis of impossibility of a cure. Such unpreparedness was attributed by participants in another study to personal difficulties and lack of contact with the subject during graduation. In view of this, strategies were chosen to read more on palliative care, to use group dynamics, to use art therapy especially with children, and to use critical-reflexive pedagogy, allowing the group to overcome the condition of object and become the subject of the knowledge produced. ${ }^{10}$ 
Another critical point stressed by the students in this process are the professors because they give greater importance to the technical activities developed within the course, than the humanistic ones, besides presenting difficulties in addressing the theme of the dying process. ${ }^{11}$

In this sense, one of the determinants of professors' inability to deal with this issue is their own professional training, since during graduation they also did not have qualified approaches or had only few opportunities to reflect on the loss, thus reproducing this absence as professors. ${ }^{11}$

Thus, professor training should receive greater influence from the knowledge of the areas of education, pedagogical, didactic and experiential knowledge. ${ }^{21}$ It is understood that a science professor is not molded from a sum of knowledge, but is constructed through the confluence of knowledge integrated to teaching practices experienced throughout their daily life. ${ }^{22}$

Thus, teaching nursing is built between the absence of pedagogical training and the persistence of conflicts and difficulties of being a professor and being a nurse in the universe of the praxis. ${ }^{23}$ In order to teach, the teaching nurse bases her teachings on her own experiences and the knowledge she seeks in the course of her experiences. ${ }^{24}$ It is necessary to rethink the formation of both the student and the educator in such a way as to include the theme of death and mourning in the teaching of both. ${ }^{25}$

From this point of view, it is evident that the discussions about this topic when they arise are presented in a fragmented, punctual and superficial way, which makes it difficult to expand understanding about death and dying, ${ }^{26}$ pointing to an insufficient academic formation to collaborate with the development of care capacities at the end of the person's life.

According to the National Curricular Guidelines of the Undergraduate Nursing Course (NCGs), the profile of the graduated professional should be based on generalist, humanistic, critical and reflexive training capable of knowing and intervening on the problems of health-disease situations. The professional needs to identify the biopsychosocial dimensions and their determinants, denoting a sense of social responsibility and commitment to citizenship as a promoter of the integrative health of the human being in their praxis, including physical and mental self-care, the search for the well-being of the population, ${ }^{26}$ and the care needs of the entire human life cycle. This includes death and dying (emphasis added).

Therefore, the nurse needs to develop skills that guarantee full assistance to the patient for his/her different needs as an individual within a family, ${ }^{26}$ which is understood as part of the moment of terminality and death that families face in their daily lives.

However, studies claim that NCGs approach some aspects quite subjectively, which may lead to different interpretations. Thus, it is understood that the teaching process should not be based only on the aspects of the NCGs alone, since they do not consolidate the necessary conditions for quality training.
The need for studies that more frequently address curricular proposals for undergraduate nursing courses is therefore stressed. $^{27}$

In this perspective, it is necessary to promote changes to the curricula of health courses in order to include topics that more deeply address the issue of death, as existing syllabuses present professional training focused on the biomedical and curative model. ${ }^{28}$

Thus, in view of the fragmented curriculum model used in the context of contemporary education, it is necessary to promote even deeper changes capable of taking apart the traditional syllabuses in order to construct an integrated curriculum that provides problem-based learning in that there is the active involvement of the student and the participation of the professor as a guide. There is also evidence of the need to incorporate interdisciplinarity into teaching practices in order to achieve more integrated training. ${ }^{29}$

In this context, based on observations of the courses of the institutions in this study and on the syllabuses of the subjects cited during the interviews, it was possible to verify how little this theme was approached in the researched setting as observed in graphic 1. The basic or foundation disciplines of the Nursing courses (UFBA, UESB, FAINOR) focus more on aspects of postmortem body care, with only the psychosocial and spiritual aspects of the patient and the family being treated in one of the syllabuses. The curricular component, Ethics and Bioethics (UFBA, FAINOR) deals only with questions of ethical conduct regarding the death process with issues such as euthanasia, dysthanasia, orthothanasia, and anticipatory guidelines. Finally, the discipline, Health of the Elderly (UESB, FAINOR) does not explicitly present the theme of death in its programmed content. It should be emphasized that only the syllabuses of the subjects mentioned by the participants during the interviews were analyzed.

Therefore, it is necessary to reflect on nursing training and practice, which points to the need for thanatology studies during graduation in order for students to learn to act in the face of the possibility of death. For this, it is initially necessary to improve the professors so that they can more safely address discussions on the theme. ${ }^{11}$

Thus, to teach nursing it is necessary to transpose the knowledge transmission process to comprehend the relationship that exists between caring, teaching and learning.

\section{Category III: Strategies to compensate or promote more substantial nurse training of care in finitude}

The third category includes suggestions brought by the subjects and includes the spheres: teaching, methodology and society contributing to the objective of this study proposes. It has the representative figure 3 of the transcendence that the professional nurse needs to develop in this universe of care in the face of human finitude. 
Figure 3. Life here and beyond. Source: designed by the research subjects.

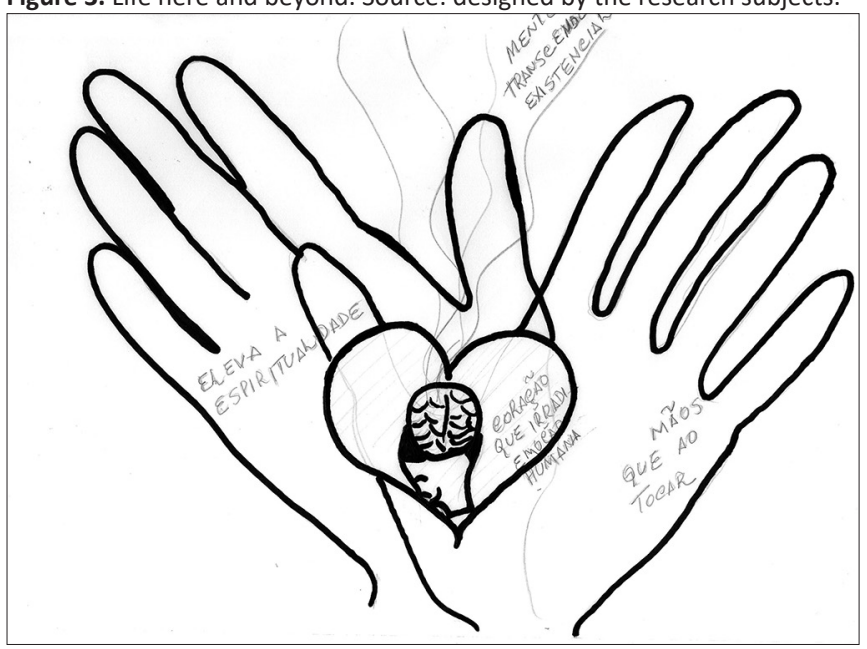

Thus, teaching is built on the mobilization of knowledge, values and perceptions, which contribute to the formation of the professor's identity. ${ }^{23}$ In this way, the professor's knowledge originates from experiences that begin within the family environment and pass through cultural experiences, and school and university education. ${ }^{22}$

It is understood from there that learning occurs through social interaction and involves previous knowledge of the individual and what the individual can still learn. ${ }^{30}$ Thus, family histories, beliefs and educational experiences before graduation exert a great influence on the performance of professors in their dealing with death, and it is therefore unwise to blame academic education alone. ${ }^{11}$

Thus, a new paradigm is proposed, in which it is necessary to transcend the reductionist and simplifying action towards interactions, reflections and self-knowledge capable of leading nurses to provide extended care. For this, it is necessary to reformulate the thinking, from the simple to the complex, from the parts to the whole, in order to interconnect and integrate disciplinary knowledge and shared experiences so that the learning is an interrelated whole, respecting the singularities of professionals and patients as active participants in an expanded, safe and effective care process. ${ }^{31}$

There are, however, no recipes or methods to teach the ideal way to deal with death. Thus, the professor must become selfaware and sensitized in a way that develops a vision of death and grieving processes, since she will be the mediator in the course of the discussions on this approach. ${ }^{23}$

In this sense, the teaching-learning process involves the ability of the educator to work and develop psycho-cognitive abilities of the person involving thought, readiness, humor and their relationship to the world, connecting with other perceptions, feelings, concerns and knowledge for practical transpersonal care. ${ }^{19}$

\section{FINAL CONSIDERATIONS}

This study responded to the objective by showing the understanding of nursing faculty about the meaning of caring in the context of end-of-life care. It pointed out that nursing care in the face of death and dying should be based on a care that permeates the spheres of the patient and family and verified that, in this setting, the theme is approached in a superficial and fragmented way during graduation. This identifies the insecurity and suffering of students to talk about death, the lack of training of nursing professors on this topic and the inadequate curricular approach to human death and dying as fragilities inherent in the discussions of this theme.

Thus, this research demonstrates the need to rethink the teaching-learning process in nursing related to care for the terminally ill so that the training of nurses is redirected to the development of nurses who work with terminality by providing greater skills that hitherto have been neglected in their significance and magnitude. From this, changes in the curriculum of nursing undergraduate courses that go beyond the inclusion of topics that discuss death and dying are suggested. It is necessary to think about and discuss a curricular model that involves interdisciplinarity and promotes cultural, philosophical, sociological and humanistic discussions about death in a context of active methodologies and investments in the permanent education of professors and nurses, increasing the possibilities of change in this context.

Thus, this research contributes to the promotion of transformations in the nursing training process in the context of the terminally ill. One limitation of this study is that the setting of the research in just one region of the state of Bahia, and therefore, its results cannot be generalized for all nursing courses. Thus, this certainly does not exhaust the theme, but encourages more investment in research, debates and educational proposals capable of mobilizing this important contemporary discussion.

\section{REFERENCES}

1. Silva RS, Pereira A, Mussi FC. Conforto para uma boa morte: perspectiva de uma equipe de enfermagem intensivista. Esc Anna Nery [Internet]. 2015 Jan/Mar; [cited 2016 Jan 5]; 19(1):40-6. Available from: http://www.scielo.br/scielo.php?script=sci_arttext\&pid =S1414-81452015000100040. DOI: 10.5935/1414-8145.20150006

2. Vasques TCS, Lunardi VL, Silva PA, Carvalho KK, Lunardi Filho WD, Barros EJL. Percepção dos trabalhadores de enfermagem acerca do cuidado ao paciente em terminalidade no ambiente hospitalar. Texto Contexto Enferm [Internet]. 2016 Sep; [cited 2017 Jul 21]; 25(3):e0480014. Available from: http://www.scielo.br/scielo. php?script=sci_arttext\&pid=S0104-07072016000300310\&lng=en. DOI: 10.1590/0104-07072016000480014.

3. Kübler-Ross E. Sobre a morte e o morrer. São Paulo: Martins Fontes; 2008

4. Freitas TLL, Banazeski AC, Eisele A, Souza EN, Bitencourt JOV, Souza SS. La visión de la Enfermería ante el Proceso de Muerte y Morir de pacientes críticos: una revisión integradora. Enferm Glob [Internet]. 2016; [cited 2017 Jul 21]; 15(41):322-34. Available from: http://scielo.isciii.es/ scielo.php?script=sci_arttext\&pid=S1695-61412016000100015\&lng=es 
5. Benedetti GMS, Oliveira K, Oliveira WT, Sales CA, Ferreira PC. Significado do processo morte/morrer para os acadêmicos ingressantes no curso de enfermagem. Rev Gaúcha Enferm [Internet]. 2013; [cited 2016 Jan 7]; 34(1):173-9. Available from: http://www.scielo. br/pdf/rgenf/v34n1/22.pdf. DOI: 10.1590/S1983-14472013000100022

6. Alves EGR, Kovács MJ. Morte de aluno: luto na escola. Psicol Esc Educ [Internet]. 2016 May/Aug; [cited 2017 Jul 21]; 2(20):403-6. Available from http://www.scielo.br/scielo.php?script=sci_arttext\&pid=S1413$85572016000200403 \&$ Ing $=e n \& n r m=i s o$. DOI: $10.1590 / 2175$ 353920150202990

7. Edo-Gual M, Tomás-Sábado J, Bardallo-Porras D, Monforte-Royo C. The impact of death and dying on nursing students: an explanatory model. J Clin Nurs [Internet]. 2014; [cited 2017 Jul 21]; 23(23-24):350112. Available from: http://pesquisa.bvsalud.org/enfermagem/resource/ $\mathrm{pt} / \mathrm{mdl}-24698364$

8. Santana JC, Santos AV, Silva BR, Oliveira DCA, Caminha EM, Peres FS, et al. Docentes de enfermagem e terminalidade em condições dignas. Rev Bioet [Internet]. 2013; [cited 2016 Jan 12]; 21(2):298-307. Available from: http://revistabioetica.cfm.org.br/index.php/revista_bioetica/ article/viewArticle/820. DOI: 10.1590/S1983-80422013000200013

9. Santos MA, Hormanez M. Atitude frente à morte em profissionais e estudantes de Enfermagem: revisão da produção científica da ultima década. Ciênc Saúde Coletiva [Internet]. 2013 Sep; [cited 2016 Jan 5]; 18(9):2757-68. Available from: http://www.scielo.br/scielo. php?script=sci_arttext\&pid=S1413-81232013000900031\&lng=en\&n rm=iso. DOI: 10.1590/S1413-81232013000900031

10. Guimarães TM, Silva LF, Espírito Santo FH, Moraes JRMM, Pacheco STA. Cuidado paliativo em oncologia pediátrica na formação do enfermeiro. Rev Gaúcha Enferm [Internet]. 2017 May; [cited 2017 Jul 22]; 38(1):e65409. Available from: http://www.scielo.br/scielo. php?script=sci_arttext\&pid=S1983-14472017000100408\&lng=en. DOI: 10.1590/1983-1447.2017.01.65409

11. Bandeira D, Cogo SB, Hidelbrant LM, Badke MR. A morte e o morrer no processo de formação de enfermeiros sob a ótica de docentes de enfermagem. Texto Contexto Enferm [Internet]. 2014; [cited 2016 Jan 7]; 23(2):400-7. Available from: http://www. index-f.com/textocontexto/2014/r23220.php. DOI: 10.1590/010407072014000660013

12. Bauer WM, Gaskell G. Pesquisa Qualitativa com texto, imagem e som: um manual prático. 10ª ed. Petrópolis: Vozes; 2015.516 p.

13. Lefevre F, Lefèvre AMC. Discourse of the collective subject: social representations and communication interventions. Texto Contexto Enferm [Internet]. 2014 Apr/Jun; [cited 2017 Feb 6]; 23(2):5027. Available from: http://www.scielo.br/scielo.php?script=sci_ arttext\&pid=S0104-07072014000200502\&lng=pt

14. Kehl KA. How hospice staff members prepare family caregivers for the patient's final days of life: An exploratory study. Palliat Med [Internet]. 2015 Feb; [cited 2017 Feb 6]; 29(2):128-37. Available from: https:// www.ncbi.nlm.nih.gov/pmc/articles/PMC4312517/?tool=pubmed

15. Gomes IM, Silva DI, Lacerda MR, Mazza VA, Méir MJ, Mercês NNA. Teoria do cuidado transpessoal de Jean Watson no cuidado domiciliar de enfermagem a criança: uma reflexão. Esc Anna Nery [Internet]. 2013 Jul/Aug; [cited 2016 Jan 7]; 17(3):555-61. Available from: http://www.scielo.br/scielo.php?script=sci_art text\&pid=S1414-81452013000300555. DOI: 10.1590/S141481452013000300021

16. Ministério da Saúde (BR). Saúde da Família: uma estratégia para a reorientação do modelo assistencial. Brasília (DF): Ministério da Saúde; 1997.

17. Kiyanda BG, Dechêne G, Marchand R. Dying at home: experience of the Verdun local community service centre. Can Fam Physician [Internet]. 2015 Apr; [cited 2016 Jan 7]; 61 (4):e215-8. Available from: https://www. ncbi.nlm.nih.gov/pmc/articles/PMC4396781/?tool=pubmed
18. Hinkle LJ, Bosslet GT, Torke AM. Factors associated with family satisfaction with end-of-life care in the ICU: a systematic review. Chest [Internet]. 2015 Jan; [cited 2016 Jan 7]; 147(1):82-93. Available from: http://journal.chestnet.org/article/S0012-3692(15)30237-3/pdf

19. Watson J. Nursing: the philosophy and science of caring. Boulder: University Press of Colorado; 2008.

20. Sales CA, Ferreira PC, Silva, VA, Oliveira TW, Marcon SS. O processo morte-morrer: definições de acadêmicos de enfermagem. Rev Rene [Internet]. 2013; [cited 2016 Feb 22]; 14(3):521-30. Available from: http:// www.revistarene.ufc.br/revista/index.php/revista/article/view/1060. DOI: 10.15253/rev\%20rene.v14i3.3425

21. De Melo Pereira FCS, Carvalho ICCM, Vale LMS, Silva NC, Morais ER. Acadêmico de enfermagem frente à morte no campo de prática hospitalar. Rev Interdisc [Internet]. 2015; [cited 2016 Feb 7]; 7(4):12430. Available from: http://revistainterdisciplinar.uninovafapi.edu.br/ index.php/revinter/article/view/356. DOI: 10.15253/rev\%20rene. v14i3.3425

22. Tardif M. Saberes docentes e formação profissional. $12^{\mathrm{a}}$ ed. Petrópolis: Vozes; 2009. 328 p.

23. Junges KS, Behrens MA. Prática docente no Ensino Superior: a formação pedagógica como mobilizadora de mudança. Perspectiva [Internet]. 2015; [cited 2016 Mar 7]; 33(1):285-317. Available from: periodicos.ufsc.br/index.php/perspectiva/article/view/2175795X.2014v33n1p285. DOI: 10.5007/2175-795X.2015v33n1p285

24. Lazzari DD, Martini JG, Busana JA. Docência no ensino superior em enfermagem: revisão integrativa de literatura. Rev Gaúcha Enferm [Internet]. $2015 \mathrm{Jul} / \mathrm{Sep}$; [cited 2016 Apr 22]; 36(3):93-101. Available from: http://www.scielo.br/scielo.php?script=sci_arttext\&pid=S198314472015000300093\&lng=en\&nrm=iso. DOI: 10.1590/19831447.2015.03.49670

25. Kovács MJ. Curso Psicologia da Morte. Educação para a morte em ação. Bol Acad Paul Psicol [Internet]. 2016 Jul; [cited 2016 Apr 22]; 36(91):400-17. Available from: http://www.redalyc.org/articulo. oa? id=94649376010

26. Ministério da Educação (BR). Diretrizes Curriculares Nacionais dos Cursos de Graduação em Enfermagem, Medicina e Nutrição. Brasília (DF): Ministério da Educação; 2001.

27. Fernandes JD, Rebouças LC. Uma década de Diretrizes Curriculares Nacionais para a Graduação em Enfermagem: avanços e desafios. Rev Bras Enferm [Internet]. 2013 Sep; [cited 2016 Feb 16]; 66(esp):95101. Available from: http://www.scielo.br/scielo.php?script=sci arttext\&pid=S0034-71672013000700013\&lng=en\&nrm=iso. DOI: 10.1590/S0034-71672013000700013

28. Souza LF, Misko MD, Silva L, Poles K, Santos MR, Bousso RS. Morte digna da criança: percepção de enfermeiros de uma unidade de oncologia. Rev Esc Enferm USP [Internet]. 2013 Feb; [cited 2016 Jan 16]; 47(1):30-7. Available from: http://www.revistas.usp.br/reeusp/ article/view/52849/. DOI: 10.1590/S0080-62342013000100004

29. Freitas DA, Santos EMS, Lima LVS, Miranda LN, Vasconcelos EL, Nagliate PC. Saberes docentes sobre processo ensino-aprendizagem e sua importância para a formação profissional em saúde. Interface (Botucatu) [Internet]. 2016 Jun; [cited 2017 Jul 21]; 20(57):43748. Available from: http://www.scielo.br/scielo.php?script=sci arttext\&pid=S1414-32832016000200437\&lng=en. DOI: 10.1590/180757622014.1177

30. Vygotsky LS. Pensamento e Linguagem. $4^{\text {a }}$ ed. São Paulo: Martins Fontes; 2008. $212 \mathrm{p}$.

31. Cruz RAO, Araujo ELM, Nascimento NM, Lima RJ, França JRFS, Oliveira JS. Reflexões à luz da Teoria da Complexidade e a formação do enfermeiro. Rev Bras Enferm [Internet]. 2017 Feb; [cited 2017 Jul 21]; 70(1):236-9. Available from: http://www.scielo.br/scielo. php? script=sci_arttext\&pid=S0034-71672017000100236\&lng=en . DOI: 10.1590/0034-7167-2016-0239 